\title{
Heavy Metal Resistant Bacteria Isolated from Hydrocarbons Contaminated Soil
}

\author{
A.A. Abd El-Hafez \\ Soil, Water and Environment Research Institute (SWERI), \\ Agricultural Research Center (ARC), Giza, Egypt.
}

\begin{abstract}
$\mathrm{A}^{\text {OUR }}$ bacterial isolates were isolated from hydrocarbons I contaminated soil from Korea. The isolated bacteria were tested for their heavy metal resistance with different concentrations of $\mathrm{Pb}^{2+}, \mathrm{Cd}^{2+}, \mathrm{Cu}^{2+}$ and $\mathrm{Cr}^{6+}\left(0-100 \mathrm{mg} \mathrm{L}^{-1}\right)$ on Tris-minimal medium using agar diffusion method. The result shows that $\mathrm{Cu}^{2+}$ and $\mathrm{Pb}^{2+}$ resistance was the most widespread. None of the tested isolates were tolerated for $\mathrm{Cr}^{6+}$. Specifically, the bacterial isolate Bacillus $\mathrm{X} 4$ was multiple metal resistances to $\mathrm{Cu}^{2+}, \mathrm{Pb}^{2+}$ and $\mathrm{Cd}^{2+}$ of concentrations 50, 50 and $10 \mathrm{mg} \mathrm{L}^{-1}$, respectively. The resistant bacterium was identified based on 16S rRNA as Bacillus megaterium X4. Results suggest that Bacillus megaterium X4. can be used to remediate heavy metals from hydrocarbons contaminated soils.
\end{abstract}

Keywords: Heavy metals, Bacillus, Hydrocarbons, Resistance, Remediation.

Heavy metal soil contamination is a significant environmental problem due to the increase in the addition of these metals to the environment. The removal of heavy metals from the environment can be grouped into two groups: 1) biotic method, which based on the accumulation of heavy metals by plants or microorganisms and 2) abiotic which based on the removal of heavy metals by using physiochemical processes such as precipitation, coprecipitation, ion exchange, and adsorption of heavy metal by a fitting adsorbent (Celis et al., 2000 and Vijayaraghavan \& Yun, 2008). However, physiochemical processes are very expensive and generate secondary products, merely resulting in a transfer of the metal from one form into less mobile and available form, but not providing a definitive solution (Kratochvil and Volesky, 1995). Biological processes have been considered as cost effective environmentally methods for the remediation of heavy metal contaminated soils (Congeevaram et al., 2007). Elevated concentration of heavy metals can form toxic complex compounds, which severely affects any biological functions (Rajbanshi, 2008).

The use of microorganisms able to survive well in high concentrations of heavy metals is of great interest as bioremediation agents. It can achieve different transformation and immobilization processes. First, the bioaccumulation based on the incorporation of metals inside the living biomass. Second, the biosorption in 
which metal ions adsorbed at the cellular surface by different mechanisms (Vijayaraghavan and Yun, 2008).

This study describes the isolation of multiple-metal resistance microorganism isolated from hydrocarbons contaminated soil of Korea.

\section{Material and Methods}

\section{Study area and sampling}

Surface soil samples were collected from hydrocarbons contaminated soil in Korea. Samples were collected from the soil surface $(0-5 \mathrm{~cm})$ and at a depth of approximately $20 \mathrm{~cm}$ and then placed in sterilized polyethylene bags using a sterilized spatula. All samples were stored at $4{ }^{\circ} \mathrm{C}$ until the examination.

\section{Chemicals and Media}

Chemicals

Stock solutions of heavy metal, i.e., $\mathrm{Cr}$ (VI), $\mathrm{Cu}(\mathrm{II}), \mathrm{Cd}$ (II) and $\mathrm{Pb}$ (II) (1000 $\mathrm{mg} \mathrm{L}^{-1}$ ) were prepared in deionized water. The elemental salts employed were $\mathrm{K}_{2} \mathrm{Cr}_{2} \mathrm{O}_{7}, \mathrm{Cu}\left(\mathrm{NO}_{3}\right)_{2}, \mathrm{Cd}\left(\mathrm{NO}_{3}\right)_{2}$ and $\mathrm{Pb}\left(\mathrm{NO}_{3}\right)_{2}$, all chemicals purchased from Sigma Aldrich (Sigma Aldrich, St. Louis, MO).

\section{Media}

Nutrient agar (Atals, 1997) was used for isolation of bacteria, Tris minimal agar medium was used to minimize the complexation with heavy metals and for determination of heavy metals tolerance (Hassan et al., 2008).

\section{Isolation of bacteria}

The soil samples were passed through a sieve $(2 \mathrm{~mm})$ to remove large pieces of debris and vegetation. The bacteria were originally isolated by plating dilutions of soils in saline solution $(0.9 \%) \mathrm{NaCl}$ on nutrient agar and incubated at $37^{\circ} \mathrm{C}$ for $48 \mathrm{hr}$ (Mira et al., 2007). Individual colonies of bacteria which varied in shape and color were picked up and purified by striking on nutrient agar. The bacterial isolates were kept on nutrient agar at $4{ }^{\circ} \mathrm{C}$ and recultured every 4 weeks. Four bacteria $(\mathrm{X} 1, \mathrm{X} 2, \mathrm{X} 3$ and $\mathrm{X} 4)$ isolated and purified and investigated for the further work.

\section{Screening of heavy metals resistant bacteria}

The isolated strains screened for its resistance using agar diffusion method (Hassan et al., 2008). The plates containing $20 \mathrm{ml}$ of Tris-minimal agar medium supplemented with different concentrations $\left(0,10,25,50\right.$, and $\left.100 \mathrm{mg} \mathrm{L}^{-1}\right)$ of chromium $\mathrm{Cr}(\mathrm{VI})$, copper $\mathrm{Cu}(\mathrm{II})$, cadmium $\mathrm{Cd}(\mathrm{II})$ and lead $\mathrm{Pb}(\mathrm{II})$. The plates inoculated with the purified bacteria and incubated at $37^{\circ} \mathrm{C}$ for $48 \mathrm{hr}$. Among the bacterial isolates, isolate $\mathrm{X} 4$ showed high resistance to heavy metals. The isolate identified using $16 \mathrm{~S}$ rRNA. 


\section{Identification of selected isolate}

The analysis of 16S rRNA genes was conducted as follows: genomic DNA was extracted from the isolated bacteria using the genomic DNA Prep kit (SolGent, Daejeon, Korea) according to the manufacture's instructions after glass bead beating to disrupt the cell wall. The extracted DNA was then used as a template for PCR to amplify the 16S rRNA gene. A universal bacterial primer set of 27F (5'-AGA GTT TGA TCC TGG CTC AG-3' and 1492R (5'-GGTTAC CTT GTT ACG ACT T-3') was used to amplify the nearly complete 16S rRNA gene. For identification of the isolated bacteria, the partial 16S rRNA gene sequence was compared with full sequence available in the GenBank database using a BLAST search (NCBI). The phylogenetic analysis of the sequence data was also performed using the software NJ plot after multiple alignments the data using CLUSTAL X (version 2.0). A distance-matrix method (with distance options according to the Kimura two-parameter model) was employed using clustering obtained with the neighbor-joining method. Bootstrap values were calculated assuming 1000 replicates.

\section{Results and Discussion}

Heavy metal resistant microorganisms play an important role in bioremediation of heavy metal contaminated soils (Abou-Shanab et al., 2007 and Ray \& Ray, 2009). The purified isolates were tested to heavy metals using agar diffusion method on Tris-minimal medium. The degree of heavy metals resistance to the highest concentration in the Tris-minimal media was evaluated based on the ability of the isolated bacteria to grow on the subsequent higher concentrations. Resistance of the bacterial isolates to different heavy metals is presented in Table 1. Most of the bacterial isolates grew well at low concentrations of the heavy metals, while no bacteria can grow at higher concentrations. A $50 \%$ of the isolates can tolerate $\mathrm{Cu}^{2+}$ and $\mathrm{Pb}^{2+}$, in contrast, the $\mathrm{Cr}^{6+}$ was the most toxic metal since no bacterial isolate could not grow even at low concentration. Among the bacterial isolate, Bacillus $\mathrm{X} 4$ showed multiplemetal resistance to $\mathrm{Cu}^{2+}\left(50 \mathrm{mg} \mathrm{L}^{-1}\right), \mathrm{Pb}^{2+}\left(50 \mathrm{mg} \mathrm{L}^{-1}\right)$ and $\mathrm{Cd}^{2+}\left(10 \mathrm{mg} \mathrm{L}^{-1}\right)$. The difference in the toxicity towards the bacterial isolates could be explained by the conditions of bacterial isolation and to the nature and the physiological characters of each bacterial isolate (Hassan et al., 2008).

Identification of the resistant strain Bacillus X4 was carried out using 16 SrRNA. The phylogenetic tree shown in Fig. 1 summarizes the phylogenetic relationships of the resistant bacterium among Bacillus species. The isolate had the highest level of $16 \mathrm{~S}$ rRNA gene sequence similarity to Bacillus megaterium sp. RKJ 600 (98\%). Thus, the isolate was identified as Bacillus megaterium X4. Based on this result Bacillus sp. X-4 was identified to be resistance for $\mathrm{Cu}, \mathrm{Pb}$ and $\mathrm{Cd}$ with concentrations up to 50,50 and $10 \mathrm{mg} \mathrm{L}^{-1}$, respectively. 
TABLE 1. Resistance of bacterial isolates to different heavy metals and concentrations.

\begin{tabular}{|c|c|c|c|c|c|}
\hline \multirow{2}{*}{ Elements } & \multirow{2}{*}{$\begin{array}{c}\text { Concentration } \\
\mathrm{mg} \mathrm{L}^{-1}\end{array}$} & \multicolumn{4}{|c|}{ Strain/Results } \\
\hline & & $\mathbf{x 1}$ & $\mathrm{x} 2$ & $\mathbf{x} 3$ & $x 4$ \\
\hline \multirow{4}{*}{ Cadmium (Cd(II)) } & 10 & - & - & - & $\sqrt{ }$ \\
\hline & 25 & - & - & - & $\sqrt{ }$ \\
\hline & 50 & - & - & - & - \\
\hline & 100 & - & - & - & - \\
\hline \multirow{4}{*}{ Copper $(\mathrm{Cu}(\mathrm{II}))$} & 10 & $\sqrt{ }$ & $\sqrt{ }$ & $\sqrt{ }$ & $\sqrt{ }$ \\
\hline & 25 & $\sqrt{ }$ & $\sqrt{ }$ & $\sqrt{ }$ & $\sqrt{ }$ \\
\hline & 50 & $\sqrt{ }$ & - & $\sqrt{ }$ & $\sqrt{ }$ \\
\hline & 100 & - & - & - & - \\
\hline \multirow{4}{*}{ Lead $(\mathrm{Pb}(\mathrm{II}))$} & 10 & $\sqrt{ }$ & $\sqrt{ }$ & $\sqrt{ }$ & $\sqrt{ }$ \\
\hline & 25 & $\sqrt{ }$ & $\sqrt{ }$ & $\sqrt{ }$ & $\sqrt{ }$ \\
\hline & 50 & - & $\sqrt{ }$ & - & $\sqrt{ }$ \\
\hline & 100 & - & - & - & - \\
\hline \multirow{4}{*}{ Chromium $(\mathrm{Cr}(\mathrm{VI}))$} & 10 & - & - & - & - \\
\hline & 25 & - & - & - & - \\
\hline & 50 & - & - & - & - \\
\hline & 100 & - & - & - & - \\
\hline
\end{tabular}

$\sqrt{\text {, Negative, -, Positive. }}$

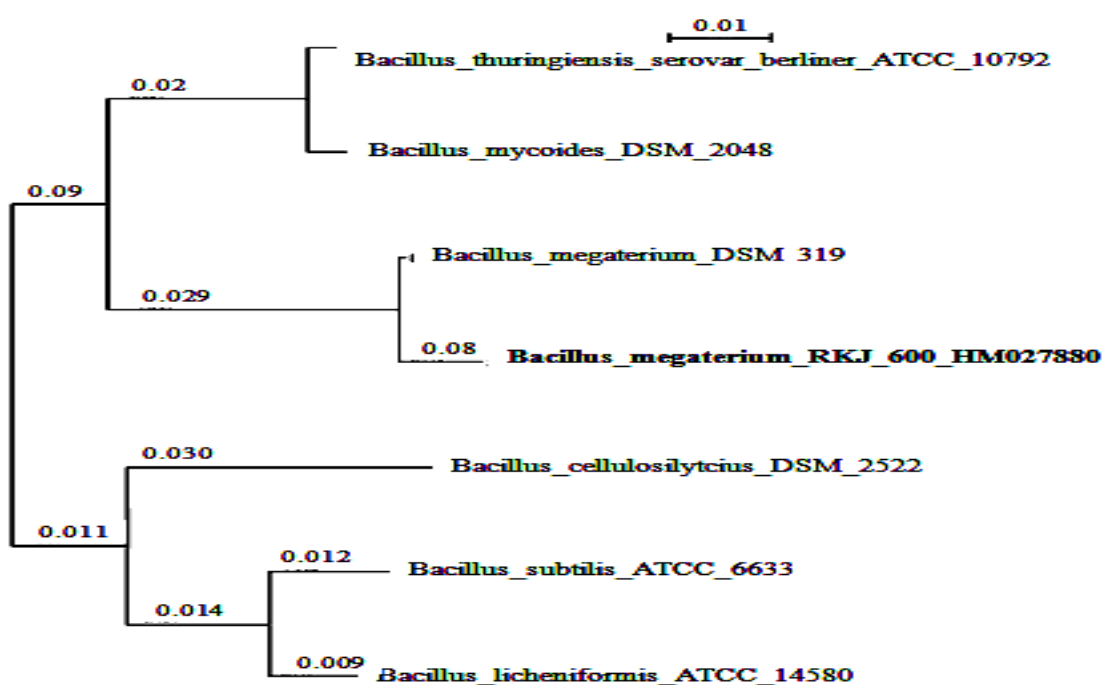

Fig. 1. The phylogenetic location of the bacterium isolates $X-4$.

Egypt. J. Soil Sci. 54, No. 1 (2014) 


\section{Conclusion}

The use of microbial populations specifically adapted to high concentrations of heavy metals, and hydrocarbons will increase the ability to remediate hydrocarbons and heavy metal contaminated soils. Our study suggests that Bacillus megaterium sp. can be useful for the remediation of hydrocarbons and heavy metal contaminated soils.

Acknowledgment : The author thanks Dr. Yong Sik Ok (Korean), associate professor, Kangwon National University and Dr. Velusamy, P. (Indian) for their valuable helps with this study.

\section{References}

Abou-Shanab, R.A.I., Van Berkum, P. and Angle, J. S. (2007) Heavy metal resistance and genotypic analysis of metal resistance genes in gram-positive and gram-negative bacteria present in Ni-rich serpentine soil and in the rhizosphere of Alyssum murale. Chemosphere 68: 360-367.

Atalas, M.R. (1997) "Hand Book of Microbiological Media", By Boca Raton, CRC Press, $2^{\text {nd }}$ ed., pp. 1026 and 1462, New York, London, Tokyo.

Celis, R., Hermosin, C.M. and Cornejo, J. (2000) Heavy metal adsorption by functionlized clays. Environmental Science and Technology 34: 4593-4599.

Congeevaram, S., Dhanarani, S., Park, J., Dexilin, M. and Thamaraiselvi, K. (2007) Biosorption of chromium and nickel by heavy metal resistant fungal and bacterial isolates. Journal of Hazardous Materials 146: 270-277.

Hassan, S.H.A., Abskharon, R.N.N., Gad El-Rab, S.M.F. and Shoreit, A.A.M. (2008) Isolation, characterization of heavy metal resistant strain of Pseudomonas aeruginosa isolated from polluted sites in Assiut city, Egypt. Journal of Basic Microbiology 48: 168-176.

Kratochvil, D. and Volesky, B. (1995) Advances in the biosorption of heavy metals. Trends in Biotechnology 16: 291-300.

Mira, T., Nelly, C., Andre, P. and Olivier, S. (2007) Monitoring of microbial activity in soil using biological oxygen demand measurement and indirect impedancemetry. Eur. J. Soil Biol. 43: 335-340.

Rajbanshi, A. (2008) Study on heavy metal resistant bacteria in Guheswori sewage treatment plant. Our Nature 6: 52-57.

Ray, S. and Ray, M.K. (2009) Bioremediation of heavy metal toxicity-with special reference to chromium. Al Ameen Journal of Medical Science 2: 57-63.

Vijayaraghavan, K. and Yun, Y.S. (2008) Bacterial biosorbents and biosorption, Biotechnology Advance 26: 266-291. 
Volesky, B. and Holan, Z.R. (1995) Biosorption of heavy metals. Biotechnology Progress 11: 235-250.

(Received 19/6/2011;

accepted 12/11/2012)

$$
\begin{aligned}
& \text { البكتريا المقاومة للعناصر الثقيلة المعزولة من الأراضى الملوثة } \\
& \text { بالّهيدروكريونات }
\end{aligned}
$$

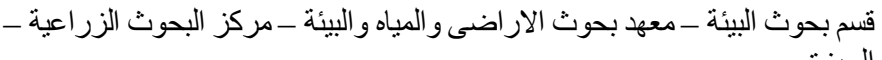

تم عزل اربع عزلات بكتيرية من الأراضى الملوثة بالهيدروكربونات في كوريا

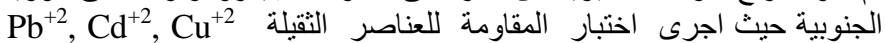

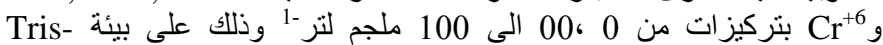

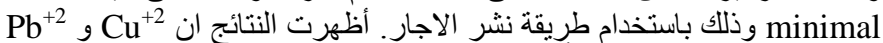

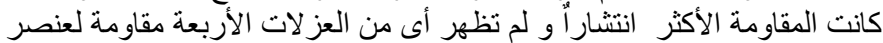

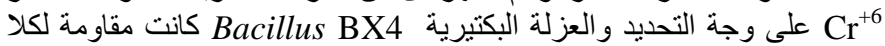
من تعريف العزلة البكتيرية BX4 أستنادا على نتائج تحليل 16SrRNA وكانت .Bacillus megaterium

توضح النتائج ان Bacillus megaterium BX4 من الممكن ان تستخدم فى معالجة العناصر الثقيلة من الأر اضى الملوثة بالهيدروكربونات. 